\title{
FORMULASI DAN UJI KINERJA ASPHALTENE DISSOLVER DENGAN PENGGUNAAN SURFAKTAN ANIONIK DARI MINYAK SAWIT
}

\section{FORMULATION AND PERFORMANCE TEST OF ASPHALTENE DISSOLVER BY USING OF PALM OIL ANIONIC SURFACTANT}

\author{
Felga Zulfia Rasdiana), Erliza Hambali2,4)*, dan Pudji Permadi',4) \\ ${ }^{1)}$ Program Studi Teknologi Industri Pertanian, Fakultas Teknologi Pertanian, Institut Pertanian Bogor \\ Kampus IPB Darmaga, Bogor 16680, Indonesia \\ ${ }^{2}$ Departemen Teknologi Industri Pertanian, Fakultas Teknologi Pertanian, Institut Pertanian Bogor \\ ${ }^{3)}$ Departemen Teknik Perminyakan, Fakultas Teknik, Institut Teknologi Bandung, Bandung, Indonesia \\ ${ }^{4)}$ Surfactant and Bioenergy Research Center, LPPM-IPB, Bogor, Indonesia \\ E-mail: erliza.h@gmail.com
}

Makalah: Diterima 9 Februari 2016; Diperbaiki 21 Juli 2016; Disetujui 20 September 2016

\begin{abstract}
Asphaltene deposition is a major problem in petroleum industry causing slow production or even operational shutdown for removal of deposits. This research was conducted to obtain the best formulation of asphaltene dissolver to dissolve asphaltene deposits with the use of an palm oil anionic surfactant and to obtain performance information of asphaltene dissolver formula. The tested formulation were methyl ester sulfonate acid (MESA) and methyl ester sulfonate (MES), each with concentrations of $0 \%, 1 \%$, 3\%, and 5\% in toluene mixed at a temperature of $40^{\circ} \mathrm{C}$ for 30 minutes. The best asphaltene dissolver produced was MESA $1 \%$ in toluene with the lowest interfacial tension (IFT) value of 3.95E-03 dyne/cm and solubility degree of 69.58\%. Asphaltene dissolver produced showed a good performance in changing the wettability of rocks with an increase on contact angle of $48,6^{\circ}$ to $80,89^{\circ}$, and increase wettability on metal surface with asphaltene release of $99.32 \%$ as well as showed good performance on dispersion, desorption and filtration.
\end{abstract}

Keywords : asphaltene, asphaltene dissolver, anionic surfactant, MESA, MES

\section{ABSTRAK}

Deposisi asphaltene merupakan masalah utama pada industri perminyakan yang menyebabkan lambatnya proses produksi atau bahkan pemberhentian proses produksi. Penelitian ini dilakukan untuk menghasilkan formulasi asphaltene dissolver terbaik yang dapat menghilangkan deposit asphaltene dengan penggunaan surfaktan anionik dari minyak sawit dan untuk mendapatkan informasi kinerja asphaltene dissolver yang dihasilkan. Formulasi yang diujikan adalah surfaktan methyl ester sulfonate acid (MESA)dan methyl ester sulfonate (MES) dengan konsentrasi masing-masing 0\%, 1\%, 3\%, 5\% dalam toluen yang dicampurkan pada suhu $40^{\circ} \mathrm{C}$ selama 30 menit. Asphaltene dissolver terbaik yang dihasilkan adalah campuran surfaktan MESA $1 \%$ dalam toluen yang menghasilkan derajat kelarutan asphaltene sebesar 69,58\% dengan nilai tegangan antarmuka terendah yaitu sebesar $3,95 \times 10^{-3}$ dyne/cm. Asphaltene dissolver yang dihasilkan menunjukkan kinerja yang baik dalam mengubah sudut kontak batuan dari $48,6^{\circ}$ menjadi $80,89^{\circ}$ dan dapat meningkatkan sifat kebasahan pada permukaan logam dengan pelepasan asphaltene sebesar 99,32\% serta memperlihatkan performa dispersi, desorpsi, dan filtrasi yang baik.

Kata kunci : asphaltene, asphaltene dissolver, surfaktan anionik, MESA

\section{PENDAHULUAN}

Asphaltene merupakan golongan fraksi berat dari minyak bumi dan diterminologikan sebagai komponen sangat aromatik berwarna hitam yang mengandung makromolekul heterosiklik tak jenuh dengan komponen utama yaitu karbon, hidrogen, dan komponen minor lain seperti sulfur, oksigen, nitrogen, serta akumulasi beberapa jenis logam berat seperti besi, nikel, vanadium, aluminium, dan magnesium. Asphaltene membentuk sistem koloid dalam minyak bumi dengan adsorpsi resin pada bagian permukaan yang membentuk stabilisasi sterik sehingga mampu mempertahankan partikel asphaltene tetap larut dalam minyak bumi (Okafor et al., 2013).

Keberadaan asphaltene di dalam minyak bumi bukanlah sebagai molekul terlarut, melainkan sebagai nanopartikel yang dapat membentuk agregat. Ketika terjadinya perubahan kondisi termodinamika selama proses produksi minyak bumi, kestabilan nanopartikel akan terganggu sehingga saling bertumbukan dan membentuk agregat yang terus tumbuh menjadi partikel yang lebih besar dari ukuran nano, mikron, sampai terbentuknya deposisi pada daur hidup produksi minyak bumi seperti perforasi, tubing, downhole, dan peralatan permukaan (Oseghale dan Ebhodaghe, 2011). 
Proses deposisi asphaltene dapat terus terjadi selama proses produksi minyak bumi sehingga jumlah endapan yang terbentuk semakin meningkat. Terbentuknya deposisi asphlatene merupakan salah satu penyebab penurunan produksi sumur minyak dan peningkatan biaya operasional produksi (Oseghale dan Ebhodaghe, 2011; Li et al., 2014) serta menjadi masalah utama pada industri perminyakan yang menyebabkan lambatnya proses produksi atau bahkan pemberhentian proses (Hashmi et al., 2012).

Salah satu upaya yang dapat dilakukan untuk mengatasi permasalahan deposisi tersebut adalah melalui injeksi langsung pelarut. Pelarut yang paling umum digunakan berasal dari golongan hidrokarbon aromatik seperti toluen, xylen atau benzen (Li et al., 2014), namun penggunaan pelarut tersebut menunjukkan performa yang kurang optimal dimana hanya menghilangkan sekitar $50 \%$ endapan asphaltene, sedangkan molekul asphaltene yang sangat polar masih menutupi bagian permukaan (Lightford et al., 2008). Upaya lain yang dapat dilakukan adalah melalui penambahan surfaktan ke dalam komposisi pelarut yang selanjutnya dinamakan dengan asphaltene dissolver. Surfaktan dapat berperan sebagai dispersant dan wetting agent yang dapat terdispersi ke dalam molekul asphaltene dengan memecah ikatan antar molekul asphaltene sehingga dapat menghambat pembentukan kembali endapan asphaltene. Akan tetapi, kebanyakan surfaktan yang digunakan adalah surfaktan komersial dari bahan baku berbasis petroleum. Surfaktan ini bersifat tidak terbarukan seiring dengan semakin berkurangnya cadangan minyak bumi. Jenis surfaktan lain yang dapat digunakan adalah surfaktan anionik yang berasal dari bahan baku nabati seperti methyl ester sulfonic acid (MESA) dan methyl ester sulfonate (MES) dari minyak sawit. Surfaktan dari minyak sawit memiliki potensi yang sangat besar untuk dikembangkan dan diaplikasikan sebagai asphaltene dissolver karena banyaknya ketersediaan bahan baku metil ester di Indonesia yang dapat disintesis menjadi surfaktan MESA dan MES. Penelitian ini bertujuan untuk menghasilkan produk asphaltene dissolver terbaik menggunakan surfaktan anionik yang berasal dari minyak sawit dan memperoleh informasi kinerja asphaltene dissolver yang dihasilkan.

\section{METODE PENELITIAN}

\section{Bahan dan Alat}

Bahan yang digunakan pada penelitian ini adalah surfaktan MESA yang berasal dari minyak sawit yang diperoleh dari SBRC LPPM IPB, air formasi, batuan formasi dan deposit asphaltene yang didapatkan dari lapangan minyak $\mathrm{A}$, toluen, xylen, solvesso 150, diesel, metil ester, $\mathrm{NaOH}$, dan aquades.
Peralatan yang digunakan dalam penelitian ini adalah spinning drop tensiometer model TX500C, densitymeter Anton Paar DMA 4500 M, viskometer Brookfield DV-III Ultra, contact angle analyser Phoenix 300, spektrofotometer UV-Vis, hotplate stirrer, core standard, $\mathrm{pH}$ meter Schott, neraca analitik Precisa XT220A, filter vakum, kertas saring whatman 42 , membran filter $0,45 \mu \mathrm{m}$, ampul, oven, vial, buret, dan gelas kimia.

\section{Tahapan Penelitian}

Persiapan Sampel Surfaktan

Pada penelitian ini digunakan dua jenis surfaktan yaitu MESA yang bersifat asam dan MES yang bersifat netral. Persiapan sampel dilakukan dengan pembuatan surfaktan MES menggunakan bahan baku surfaktan MESA (bersifat asam) yang dinetralisasi dengan menggunakan $\mathrm{NaOH} 50 \%$ hingga mencapai $\mathrm{pH}$ netral atau berkisar 6-7. Surfaktan MESA dan MES yang telah dibuat selanjutnya dianalisis sifat fisikokimia meliputi: pengukuran $\mathrm{pH}$ menggunakan $\mathrm{pH}$ meter Schott, kadar bahan aktif dengan titrasi dua fasa, pengukuran densitas menggunakan densitymeter Anton Paar DMA 4500 M dan viskositas menggunakan viskometer Brookfield DV-III Ultra.

\section{Formulasi Asphaltene Dissolver \\ Pemilihan Jenis Pelarut Terbaik}

Formulasi asphaltene dissolver diawali dengan pemilihan jenis pelarut terbaik untuk digunakan sebagai dissolver. Jenis pelarut yang digunakan yaitu toluen, xylen, solvesso, diesel, dan metil ester. Pemilihan jenis pelarut terbaik berdasarkan efektivitasnya dalam melarutkan asphaltene. Pengujian kelarutan asphaltene dilakukan secara gravimetri yang merujuk pada metode yang digunakan Salgaonkar dan Danait (2012) dengan modifikasi. Sebanyak $10 \mathrm{~mL}$ dissolver ditempatkan dalam vial, kemudian ditambahkan $1 \mathrm{~g}$ deposit asphaltene. Vial ditutup dan diaduk selama 15 detik, lalu didiamkan selama 1 jam pada suhu ruang. Setelah perendaman, sampel kemudian disaring menggunakan kertas saring Whatman 42. Partikel padat dibilas dengan isopropil alkohol dan dikeringkan pada suhu ruang selama 6 jam. Selanjutnya padatan kering dan kertas saring ditimbang. Kelarutan diperoleh dari selisih bobot awal dan bobot akhir asphaltene.

\section{Penentuan Konsentrasi Surfaktan}

Pelarut terbaik yang terpilih selanjutnya diformulasikan dengan dua jenis surfaktan yaitu surfaktan MESA (bersifat asam) dan MES (bersifat netral) dengan konsentrasi masing-masing 0\%, $1 \%$, $3 \%, 5 \%$ dan diformulasikan dalam gelas kimia pada hotplate stirer dengan pengadukan $300 \mathrm{rpm}$, suhu $40^{\circ} \mathrm{C}$ selama 30 menit, kemudian didiamkan pada suhu ruang. Selanjutnya, setiap larutan dilakukan pengukuran tegangan antarmuka menggunakan 
spinning drop tensiometer dan pengukuran kelarutan asphaltene berdasarkan modifikasi metode yang digunakan Salgaonkar dan Danait (2012). Konsentrasi surfaktan terkecil yang memberikan nilai tegangan antarmuka terendah dan kelarutan asphaltene tertinggi ditetapkan sebagai konsentrasi terpilih. Desain eksperimen yang digunakan adalah rancangan acak lengkap faktor tunggal dengan dua kali pengulangan.

\section{Kinerja Asphaltene Dissolver}

Kinerja asphaltene dissolver dilakukan dengan pengujian pada formula dengan jenis dan konsentrasi surfaktan terbaik. Kinerja yang diujikan meliputi pengukuran dispersi asphaltene dissolver, desorpsi asphaltene dari batuan, wettability batuan, wetting characteristic pada permukaan logam serta filtration ratio. Pengujian kinerja juga dilakukan menggunakan toluen saja sebagai pembanding.

\section{Dispersi Asphaltene Dissolver}

Pengujian dispersi dilakukan berdasarkan modifikasi Minssieux (2001) dengan melarutkan sebanyak $20 \mathrm{mg}$ asphaltene ke dalam $100 \mathrm{~mL}$ toluen. Campuran dikocok selama 60 menit dengan kecepatan $300 \mathrm{rpm}$ pada suhu ruang, kemudian didiamkan selama 60 menit dan dilakukan penyaringan menggunakan filter membran 0,45 $\mu \mathrm{m}$. Selanjutnya, konsentrasi asphaltene di dalam larutan ditentukan melalui pengukuran absorbansi pada panjang gelombang $300 \mathrm{~nm}$ menggunakan spektrofotometer UV-Vis. Absorbansi campuran yang tidak ditambahkan surfaktan dibandingkan dengan campuran yang ditambahkan surfaktan sebanyak $1 \%$ pada kondisi yang sama.

\section{Desorpsi Asphaltene dari Batuan}

Uji desorpsi asphaltene dilakukan berdasarkan metode Minssieux (2001) dengan modifikasi. Proses pengujian dilakukan dengan mempersiapkan larutan $20 \mathrm{mg}$ asphaltene dalam $100 \mathrm{~mL}$ toluen, kemudian ke dalam larutan ditambahkan sebanyak $5 \mathrm{~g}$ batuan karbonat yang sebelumnya telah dicuci dengan toluen dan digerus untuk mengecilkan ukuran hingga berbentuk bubuk. Campuran diaduk selama 60 menit dengan kecepatan $300 \mathrm{rpm}$ pada suhu ruang, kemudian didiamkan selama 60 menit dan dilakukan penyaringan menggunakan filter membran $0,45 \mu \mathrm{m}$. Campuran larutan yang ditambahkan surfaktan sebanyak $1 \%$ juga dipersiapkan pada kondisi yang sama. Konsentrasi asphaltene di dalam larutan ditentukan melalui pengukuran absorbansi pada panjang gelombang $300 \mathrm{~nm}$ menggunakan spektrofotometer UV-Vis.

\section{Wettability pada Batuan (SBRC, 2012)}

Pengujian dilakukan dengan mengukur sudut kontak $(\theta)$ yang terbentuk oleh permukaan padatan dengan garis singgung terhadap permukaan fluida pada titik kontak dengan padatannya. Sampel batuan karbonat yang akan diuji sudut kontaknya dengan minyak awalnya dilakukan proses pencucian dengan toluen. Pengujian dilakukan dengan empat tahap perendaman. Tahap perendaman yang dilakukan, yaitu perendaman dalam air formasi, perendaman dalam minyak, perendaman dengan menggunakan asphaltene dissolver, dan perendaman kembali dengan menggunakan air formasi. Semua perendaman batuan dilakukan pada suhu reservoir $\left(110^{\circ} \mathrm{C}\right)$.

\section{Wetting Characteristic pada Permukaan Logam \\ Pengujian dilakukan berdasarkan metode yang dilakukan Frost et al. (2008) dengan modifikasi. Pengujian dilakukan dengan menimbang sebanyak $2 \mathrm{~g}$ sampel asphaltene, kemudian disiapkan wadah jar dan potongan logam. Sampel asphaltene dioleskan pada potongan logam dan ditempatkan dalam jar, kemudian ditambahkan larutan asphaltene dissolver sebanyak $20 \mathrm{~mL}$ dan dilakukan perendaman selama 30 menit yang diikuti dengan sedikit pengadukan. Kemudian potongan logam diangkat dan diamati perubahan yang terjadi secara visual dan dilakukan penimbangan pertambahan bobot logam setelah perendaman. Percobaan juga dilakukan dengan toluen pada kondisi yang sama sebagai perbandingan. Pertambahan bobot logam diperoleh dari selisih bobot awal dan bobot akhir logam.}

\section{Filtration Ratio (SBRC, 2012)}

Pengujian filtrasi dilakukan dengan menyaring formula asphaltene dissolver menggunakan filter apparatus yang dilengkapi dengan tangki nitrogen, pressure vessel, dan membrane filter holder pada tekanan 20 psig. Sebanyak 200-250 mL larutan sampel dimasukkan ke dalam pressure vessel lalu ditutup hingga rapat. Graduated cylinder ditempatkan di bawah outlet filter lalu katup pada dasar filter pressure vessel dibuka dan waktu dihitung dengan menggunakan stopwatch. Tekanan yang digunakan (20 psig) dipertahankan konstan dan dipastikan larutan dalam filter sesuai dengan suhu reservoir. Waktu kumulatif dari tiap kenaikan filter sebanyak $20 \mathrm{~mL}$ dicatat. Filtrasi dilanjutkan sampai $200 \mathrm{~mL}$ larutan sudah terfiltrasi. Laju alir dari bahan diketahui dari filtration ratio (FR) melalui perhitungan menggunakan rumus :

$$
\mathrm{FR}=\frac{t 200-t 180}{t 80-t 60}<1.2
$$

Dimana $\mathrm{t}=$ waktu

\section{HASIL DAN PEMBAHASAN}

\section{Persiapan Sampel Surfaktan}

Surfaktan MES dibuat dari surfaktan MESA melalui proses netralisasi dengan menggunakan $\mathrm{NaOH} 50 \%$. Surfaktan MESA sendiri 
diproduksi melalui proses sulfonasi fatty acid methyl ester (FAME). Sifat fisikokimia surfaktan MESA dan MES dipengaruhi oleh faktor-faktor yang terjadi selama proses sulfonasi dan netralisasi. Analisis sifat fisikokimia surfaktan yang dilakukan meliputi pengukuran kadar bahan aktif, $\mathrm{pH}$, densitas, dan viskositas disajikan pada Tabel 1 .

Tabel 1. Sifat fisikokimia surfaktan

\begin{tabular}{lcc}
\hline \multicolumn{1}{c}{ Parameter } & MESA & MES \\
\hline Kadar bahan aktif $(\%)$ & 24,08 & 23,51 \\
Densitas $\left(\mathrm{g} / \mathrm{cm}^{3}\right)$ & 0,83 & 0,94 \\
Viskositas $(\mathrm{cP})$ & 19,2 & 25,5 \\
Nilai pH & 0,88 & 6,39 \\
\hline
\end{tabular}

Analisis sifat fisikokimia menunjukkan bahwa densitas MES lebih besar dibandingkan MESA dengan nilai $0,94 \mathrm{~g} / \mathrm{cm}^{3}$ dan $0,83 \mathrm{~g} / \mathrm{cm}^{3}$, hal ini berkorelasi dengan viskositas dimana MES lebih kental dengan nilai viskositas yang lebih tinggi dibandingkan dengan MESA. Hasil analisis kandungan bahan aktif sampel surfaktan MESA adalah 24,08\% dan surfaktan MES sebesar 23,51\%. Kadar bahan aktif merupakan parameter yang menunjukkan kualitas surfaktan. Semakin tinggi kandungan bahan aktif maka semakin baik kinerja surfaktan tersebut.

Surfaktan MESA memiliki pH sebesar 0,88 yang berarti memiliki derajat keasaman yang sangat tinggi. pH MESA yang rendah disebabkan oleh adanya gugus sulfonat yang terdapat dalam produk hasil sulfonasi karena keberadaan molekul $\mathrm{SO}_{3}$ yang bersifat asam. Untuk memperoleh surfaktan MES perlu dilakukan netralisasi menggunakan $\mathrm{NaOH}$ $50 \%$. Penambahan $\mathrm{NaOH}$ pada proses netralisasi akan mempengaruhi struktur molekul MESA karena adanya ikatan yang terbentuk antara ion $\mathrm{Na}^{+}$dan gugus sulfonat surfaktan sehingga menghasilkan surfaktan MES dan $\mathrm{H}_{2} \mathrm{O}$ sebagai produk samping dimana $\mathrm{H}_{2} \mathrm{O}$ teruapkan saat pemanasan sehingga menyebabkan pH MES meningkat menjadi 6,39. Derajat keasaman atau $\mathrm{pH}$ akan mempengaruhi efektifitas pelarutan asphaltene. Menurut Hashmi et al. (2012), mekanisme dispersi surfaktan terhadap molekul asphaltene melibatkan sifat keasamaan surfaktan tersebut.

\section{Formulasi Asphaltene Dissolver} Pemilihan Jenis Pelarut Terbaik

Tahap awal yang dilakukan dalam formulasi asphaltene dissolver adalah penentuan jenis pelarut terbaik. Pelarut yang digunakan adalah toluen, xylen, solvesso, diesel, dan metil ester. Kelarutan asphaltene merupakan parameter yang digunakan untuk mendapatkan jenis pelarut terbaik dengan nilai kelarutan tertinggi. Hasil pengukuran pengaruh jenis pelarut terhadap kelarutan asphaltene disajikan pada Gambar 1.

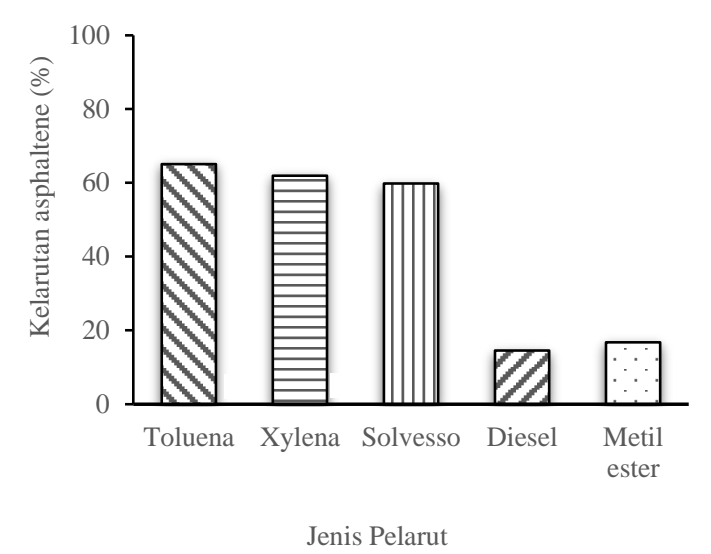

Gambar 1. Kelarutan asphaltene pada berbagai jenis pelarut

Gambar 1 menunjukkan bahwa masingmasing jenis pelarut memberikan nilai kelarutan yang berbeda. Kelarutan yang terendah diperoleh pada penggunaan pelarut diesel dengan kelarutan sebesar 14,56\%, sedangkan kelarutan tertinggi didapatkan pada penggunaan toluen dengan kelarutan sebesar $65,09 \%$. Pada penggunaan pelarut xylen, solvesso, dan metil ester diperoleh kelarutan masing-masing sebesar 61,95\%, 59,84\%, dan $16,83 \%$. Dari keseluruhan perlakuan yang diujikan, toluen memberikan kelarutan paling tinggi diantara jenis pelarut lainnya sehingga toluen merupakan pelarut terpilih berdasarkan nilai kelarutan tertinggi. Karakteristik kelarutan pelarut asphaltene dapat dilihat berdasarkan Hansen solubility parameter seperti yang disajikan pada Tabel 2.

Tabel 2. Karakteristik kelarutan pelarut berdasarkan Hansen solubility parameter

\begin{tabular}{cccc}
\hline Sampel & $\begin{array}{c}\boldsymbol{\delta}_{\mathbf{D}}(\text { dispersion interaction }) \\
\left(\mathbf{M p a}^{1 / 2}\right)\end{array}$ & $\begin{array}{c}\boldsymbol{\delta}_{\mathbf{p}} \text { (permanent dipole } \\
\text { interaction })\left(\mathbf{M p a}^{1 / 2}\right)\end{array}$ & $\begin{array}{c}\boldsymbol{\delta}_{\mathbf{H}}(\text { hydrogen bonding }) \\
\left(\mathbf{M p a}^{\mathbf{1} / 2}\right)\end{array}$ \\
\hline Asphaltene & 19,6 & 3,4 & 4,4 \\
Toluen & 18,0 & 1,4 & 2,0 \\
Xylen & 17,6 & 1,0 & 3,1 \\
Benzen & 18,4 & 0,0 & 2,0 \\
\hline
\end{tabular}

Sumber: Hansen (2007) 
Menurut Hansen solubility parameter, terdapat tiga kriteria yang menentukan pemilihan pelarut yang sesuai dengan karakteristik kelarutan asphaltene, kriteria tersebut yaitu $\delta_{\mathrm{D}}$ (dispersion interaction) melalui interaksi non polar, $\delta_{\mathrm{p}}$ (permanent dipole interaction) yang merupakan interaksi polar, dan $\delta_{\mathrm{H}}$ (hydrogen bonding) interaksi yang ditimbulkan melalui ikatan hidrogen antara molekul asphaltene dan pelarut.

Berdasarkan tiga kriteria tersebut, toluen menunjukkan nilai yang paling mendekati nilai kelarutan asphaltene dibandingkan dengan xylen. Toluen merupakan jenis pelarut hidrokarbon aromatik dengan rumus molekul $\mathrm{C}_{6} \mathrm{H}_{5} \mathrm{CH}_{3}$ memiliki densitas $0,866 \mathrm{~g} / \mathrm{cm}^{3}$, titik didih $110,6^{\circ} \mathrm{C}$, dan flash point sebesar $4^{\circ} \mathrm{C}$. Toluen tergolong dalam pelarut aromatik homosiklik yang mengandung cincin aromatik.

Oseghale dan Ebhodaghe (2011) melakukan pengujian pelarutan asphaltene dalam toluen, diesel dan campuran keduanya pada beberapa variasi konsentrasi. Hasil penelitiannya menunjukkan bahwa kelarutan asphaltene paling optimal diperoleh pada toluen dengan konsentrasi $100 \%$, sedangkan campuran kedua pelarut menunjukkan hasil yang kurang baik bahkan diesel hanya dapat melarutkan asphaltene kurang dari $15 \%$ dalam waktu 150 menit.

\section{Penentuan Konsentrasi Surfaktan}

\section{Tegangan Antarmuka}

Pengukuran tegangan antarmuka merupakan salah satu parameter yang menentukan kinerja surfaktan, diharapkan formula tersebut mampu menurunkan tegangan antar muka minyakair mencapai nilai terendah dengan nilai ultra-low interfacial tension $\left(\leq 10^{-3}\right.$ dyne $\left./ \mathrm{cm}\right)$. Hal ini disyaratkan karena dengan nilai tegangan antarmuka yang sangat rendah akan memperbesar nilai capillary number, serta mengubah kondisi batuan suka minyak (oil wet) menjadi suka air (water wet) agar proses pelarutan asphaltene dapat dilakukan secara optimal dan pengendapan kembali deposisi asphaltene dapat dicegah. Untuk memperoleh kinerja terbaik dari surfaktan, maka dilakukan proses formulasi untuk menentukan jenis dan konsentrasi surfaktan terbaik. Pada tahapan ini toluen sebagai pelarut terpilih diformulasikan dengan surfaktan MESA dan MES.

Hasil pengukuran tegangan antarmuka menunjukkan nilai yang bervariasi dengan kisaran antara $3,95 \times 10^{-3}$ dyne/cm hingga $1,71 \times 10^{-2}$ dyne $/ \mathrm{cm}$ pada penambahan MESA dan kisaran nilai $1,19 \times 10^{-2}$ dyne/cm sampai $2,80 \times 10^{-2}$ dyne/cm pada penambahan MES. Berdasarkan hasil tersebut diketahui bahwa surfaktan MESA menunjukkan kinerja yang lebih baik daripada surfaktan MES dalam menurunkan nilai tegangan antarmuka. Nilai tegangan antarmuka terkecil diperoleh pada surfaktan dengan konsentrasi $1 \%$. Kecenderungan yang terjadi adalah pada saat konsentrasi surfaktan $1 \%$ ditambahkan dalam toluen terjadi penurunan tegangan antarmuka sampai tegangan antarmuka terkecil yaitu sebesar $3,95 \times 10^{-3}$ dyne $/ \mathrm{cm}$ pada penggunaan surfaktan MESA, kemudian tegangan antarmuka kembali meningkat pada konsentrasi surfaktan $3 \%$ dan 5\%. Hal yang sama terjadi pada penggunaan surfaktan MES. Dari kedua jenis surfaktan yang diujikan, nilai tegangan antarmuka MESA yang dihasilkan relatif lebih rendah dibandingkan MES pada konsentrasi yang sama.

Hasil sidik ragam menunjukkan bahwa perlakuan konsentrasi surfaktan berpengaruh nyata (signifikan pada tingkat kepercayaan 95\%) terhadap penurunan nilai tegangan antarmuka. Uji lanjut Duncan terhadap konsentrasi surfaktan menunjukkan bahwa taraf konsentrasi $0 \%$ menghasilkan pengaruh yang berbeda nyata terhadap penurunan nilai tegangan antarmuka dengan perlakuan $1 \%, 3 \%$, dan $5 \%$ pada tingkat kepercayaan $95 \%$ pada kedua jenis surfaktan baik MESA maupun MES. Faktor konsentrasi pada taraf perlakuan 1\%, 3\%, dan 5\% memberikan pengaruh yang tidak berbeda nyata. Faktor konsentrasi surfaktan MESA 1\% memberikan rata-rata nilai tegangan antarmuka terendah sebesar $3,95 \times 10^{-3} \mathrm{dyne} / \mathrm{cm}$ dan rataan penurunan tegangan antarmuka tertinggi sebesar 99,97\%. Hasil pengukuran tegangan antarmuka ditampilkan pada Gambar 2.

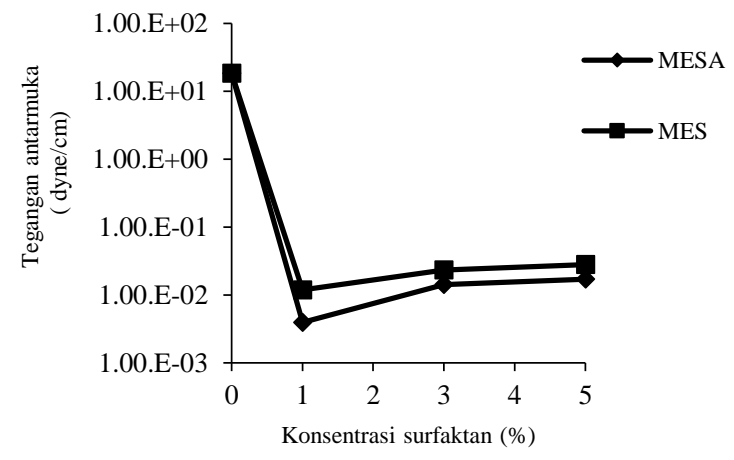

Gambar 2. Nilai tegangan antarmuka beberapa konsentrasi surfaktan MESA dan MES dalam toluen

Adsorpsi surfaktan akan menyebabkan penurunan energi bebas pada daerah antarmuka. Energi bebas antarmuka atau interfacial tension adalah jumlah kerja minimum yang dibutuhkan untuk memperluas daerah antarmuka. Semakin banyak surfaktan yang teradsorpsi, penurunan interfacial tension akan semakin besar. Namun, saat mencapai konsentrasi tertentu, tegangan antarmuka akan konstan, walaupun konsentrasi surfaktan terus ditingkatkan. Bila surfaktan ditambahkan melebihi konsentrasi ini maka akan terbentuk misela. Konsentrasi pada saat terbentuk misela disebut critical micelle concentration (CMC). Setelah CMC 
tercapai, tegangan permukaan akan konstan yang menunjukkan bahwa daerah antarmuka menjadi jenuh sehingga terbentuk misela yang berada dalam keseimbangan dinamis dengan monomernya (Tadros, 2005). Surfaktan diduga mencapai critical micelle concentration (CMC) pada konsentrasi 1\%, sehingga peningkatan konsentrasi surfaktan 3\% dan $5 \%$ menyebabkan peningkatan nilai tegangan antarmuka.

\section{Kelarutan Asphaltene}

Proses pengujian dilanjutkan dengan penentuan konsentrasi terbaik surfaktan dalam asphaltene dissolver untuk meningkatkan pelarutan asphaltene. Penentuan konsentrasi surfaktan terbaik dilihat dari kelarutan yang dihasilkan oleh larutan tersebut. Hasil pengukuran kelarutan asphaltene menunjukkan bahwa kelarutan asphaltene tertinggi diperoleh pada konsentrasi surfaktan $1 \%$, kemudian mengalami penurunan pada konsentrasi $3 \%$ dan $5 \%$. Kecenderungan penurunan kelarutan asphaltene terjadi pada kedua jenis surfaktan yang digunakan baik MESA maupun MES. Dari kedua jenis surfaktan tersebut, surfaktan MESA menghasilkan kelarutan tertinggi dibandingkan surfaktan MES. Kelarutan tertinggi diperoleh pada surfaktan MESA $1 \%$ dengan nilai mencapai $69,58 \%$, sedangkan pada surfaktan MES $1 \%$ hanya mencapai nilai sebesar $67,47 \%$.

Hasil sidik ragam menunjukkan bahwa perlakuan konsentrasi surfaktan berpengaruh nyata (signifikan pada tingkat kepercayaan 95\%) terhadap kelarutan asphaltene. Uji lanjut Duncan terhadap konsentrasi surfaktan MES menunjukkan bahwa taraf konsentrasi $1 \%$ menghasilkan pengaruh yang berbeda nyata terhadap konsentrasi surfaktan lainnya pada tingkat kepercayaan 95\%. Begitu juga halnya pada surfaktan MESA menunjukkan bahwa konsentrasi $1 \%$ memberikan pengaruh yang berbeda nyata dengan konsentrasi $3 \%$ dan 5\%, sedangkan konsentrasi $3 \%$ dan 5\% menunjukkan pengaruh yang tidak berbeda nyata. Faktor konsentrasi surfaktan MESA $1 \%$ memberikan rata-rata kelarutan asphaltene tertinggi sebesar $69,58 \%$. Kriteria yang ditetapkan dalam pemilihan jenis dan konsentrasi surfaktan adalah konsentrasi surfaktan terkecil yang memberikan nilai tegangan antarmuka terendah dan derajat kelarutan tertinggi yang kemudian ditetapkan sebagai konsentrasi terbaik. Dengan demikian, berdasarkan hasil percobaan ini ditetapkan konsentrasi terbaik surfaktan adalah $1 \%$ pada penggunaan surfaktan MESA. Hasil pengukuran kelarutan asphaltene disajikan pada Gambar 3.

Kemampuan surfaktan untuk teradsorpsi di permukaan partikel asphaltene merupakan hal yang sangat penting dalam mekanisme pelarutan asphaltene. Surfaktan yang bersifat asam dapat teradsorpsi di permukaan partikel asphaltene dengan sangat kuat. Sebaliknya, surfaktan yang bersifat netral atau basa memiliki kemampuan yang lemah untuk teradsorpsi di permukaan partikel asphaltene. Hal ini mengindikasikan bahwa ikatan hidrogen yang terbentuk antara gugus asam pada surfaktan dengan gugus basa pada partikel asphaltene lebih kuat dibandingkan dengan ikatan hidrogen gugus basa surfaktan dengan gugus asam asphaltene (Oslund et al., 2004). Dalam arti kata bahwa meskipun sama-sama dapat membentuk ikatan hidrogen dengan partikel asphaltene, namun daya dispersi surfaktan asam relatif lebih baik dibandingkan dengan surfaktan basa atau netral.

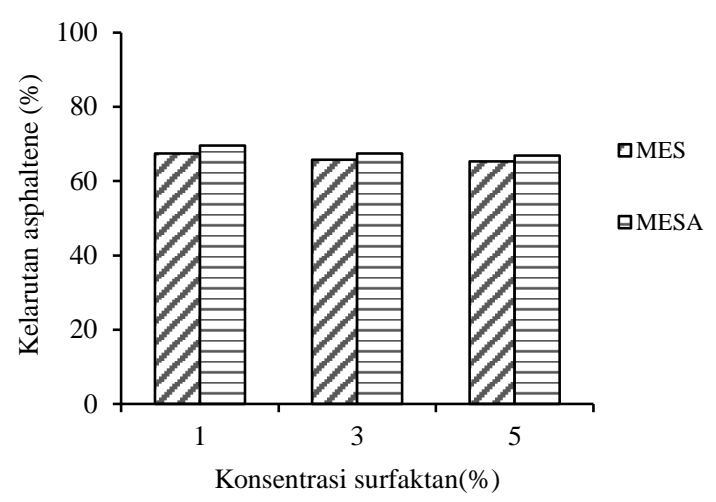

Gambar 3. Derajat kelarutan asphaltene pada beberapa konsentrasi surfaktan MESA dan MES dalam toluen

Leon et al. (2001) mengemukakan bahwa kestabilan asphaltene meningkat seiring dengan peningkatan konsentrasi surfaktan yang teradsorpsi di permukaan partikel asphaltene. Namun adsorpsi ini dibatasi oleh beberapa faktor, diantaranya adalah luas bidang aktif partikel asphaltene dan konsentrasi terbaik surfaktan yang dapat teradsorpsi di permukaan partikel asphaltene. Hal ini diduga menjadi penyebab menurunnya kelarutan asphaltene pada konsentrasi di atas $1 \%$. Sempitnya bidang aktif dan rendahnya kapasitas adsorpsi menyebabkan partikel asphaltene cepat jenuh, sehingga pengaruh peningkatan konsentrasi surfaktan di atas $1 \%$ tidak sebesar saat konsentrasi $1 \%$.

\section{Kinerja Asphaltene Dissolver}

Dispersi Asphaltene Dissolver

Dalam upaya meningkatkan kemampuan pelarutan asphaltene, penting untuk mengetahui efektifitas dispersi asphaltene dissolver pada partikel asphaltene. Mekanisme dispersi asphaltene dissolver dapat terjadi karena adanya interaksi asambasa antara gugus sulfonat surfaktan MESA dengan gugus basa asphaltene. Surfaktan dapat memecah ikatan antar molekul asphaltene dan mendispersi molekul asphaltene ke dalam pelarut sehingga dapat dilarutkan. Pengujian dispersi surfaktan dilakukan dengan menggunakan spektrofotometer UV-Vis pada panjang gelombang $300 \mathrm{~nm}$. 
Hasil pengukuran campuran asphaltene dalam toluen memberikan nilai absorbansi sebesar 0,902, sedangkan nilai absorbansi campuran asphaltene dalam toluen yang ditambahkan MESA $1 \%$ memberikan nilai sebesar 1,179 . Nilai absorbansi campuran asphaltene dalam toluen lebih rendah dibanding absorbansi larutan yang ditambahkan surfaktan MESA 1\%. Peningkatan nilai absorbansi larutan asphaltene dissolver menunjukkan bahwa penambahan surfaktan MESA berpengaruh terhadap peningkatan kestabilan asphaltene dalam larutan.

Surfaktan MESA memiliki gugus sulfonat $\left(\mathrm{SO}_{3} \mathrm{H}\right)$ yang bersifat sangat asam sehingga dapat berinteraksi dengan asphaltene melalui interaksi asam-basa. Pola interaksi surfaktan MESA dengan partikel asphaltene diduga mirip dengan resin, yang merupakan peptizing agent alami asphaltene dalam minyak bumi. Gugus asam surfaktan yang terikat pada partikel asphaltene memungkinkan pembentukan lapisan stabilisasi sterik oleh rantai samping surfaktan. Lapisan stabilisasi sterik bersifat non polar, sehingga dapat mendispersi asphaltene ke dalam pelarut. Selain itu, lapisan stabilisasi sterik dapat mencegah pembentukan dimer asphaltene sehingga peningkatan ukuran partikel asphaltene dapat dicegah (Hashmi et al., 2012).

\section{Desorpsi Asphaltene dari Batuan}

Desorpsi didefinisikan sebagai peristiwa pelepasan molekul atau ion dari permukaan zat padat. Uji desorpsi bertujuan untuk melihat seberapa besar efektifitas surfaktan meningkatkan kemampuan pelepasan partikel asphaltene yang sebelumnya teradsorpsi pada batuan. Jumlah desorpsi ditentukan dari perubahan nilai absorbansi sebelum dan sesudah penambahan surfaktan. Pengujian desorpsi surfaktan dilakukan dengan menggunakan spektrofotometer UV-Vis pada panjang gelombang $300 \mathrm{~nm}$. Panjang gelombang $300 \mathrm{~nm}$ merupakan panjang gelombang spesifik terhadap fraksi asphaltene yang diperoleh melalui scanning terhadap larutan asphaltene di dalam toluen pada rentangan panjang gelombang 200-700 nm (Ghaffar et al., 2013).

Hasil pengukuran campuran asphaltene dalam toluen memberikan nilai absorbansi sebesar 0,863, sedangkan nilai absorbansi campuran asphaltene dalam toluen yang ditambahkan MESA $1 \%$ memberikan nilai sebesar 1,152 . Peningkatan nilai absorbansi menunjukkan bahwa terjadinya pelepasan partikel asphaltene dari permukaan batuan dan membentuk kestabilan dalam larutan oleh kehadiran surfaktan. Surfaktan MESA dapat memutus ikatan antar molekul asphaltene yang menahannya pada permukaan batuan dan menggantinya dengan ikatan surfaktan dan asphaltene yang berinteraksi melalui ikatan asambasa (Lightford et al., 2008).

\section{Wettability pada Batuan}

Wettability merupakan indikator yang menunjukkan interaksi molekuler antara cairan dan padatan melalui interaksi langsung pada daerah antarmuka dan secara umum direpresentasikan dalam sudut kontak (Zhang, 2004). Batuan dapat dikatakan bersifat oil wet, apabila sudut kontak yang dibentuk antara batuan dan minyak adalah $<90^{\circ}$ dan bersifat water wet apabila sudut kontak yang dibentuk adalah $>90^{\circ}$. Semakin besar sudut kontak antara batuan dengan minyak maka semakin sempurna tingkat pembasahan batuan oleh larutan surfaktan.

Hasil pengujian sudut kontak pada sampel batuan yang digunakan untuk asphaltene dissolver yang dihasilkan menunjukkan bahwa terjadi perubahan sudut kontak batuan pada setiap tahap perendaman. Sudut kontak yang terbentuk semakin tinggi pada setiap peningkatan tahapan perendaman. Pada tahap pertama pengujian menunjukkan bahwa sampel batuan yang digunakan untuk pengujian wettability memiliki sifat oil wet karena sudut kontak yang dihasilkan masih relatif kecil dengan nilai sudut kontak awal $34,67^{\circ}$ pada sampel batuan yang digunakan untuk toluen dan $48,6^{\circ}$ pada sampel batuan yang digunakan untuk asphaltene dissolver. Pada tahap kedua, sudut kontak yang dihasilkan mengalami peningkatan, begitu juga halnya dengan tahap ketiga dan tahap keempat sudut kontak batuan mengalami peningkatan yang cukup signifikan. Nilai sudut kontak tertinggi diperoleh pada sampel batuan yang digunakan untuk asphaltene dissolver dengan nilai $80,89^{\circ}$, sedangkan pada sampel batuan yang digunakan untuk toluen hanya sebesar 53,38 . Hasil pengujian ini menunjukkan bahwa terjadi peningkatan sudut kontak batuan sebesar 32,29 pada sampel batuan yang digunakan untuk asphaltene dissolver dan sebesar $18,71^{\circ}$ pada sampel batuan yang digunakan untuk toluen. Peningkatan sudut kontak yang terbentuk antara batuan dengan minyak pada asphaltene dissolver lebih tinggi dibandingkan toluen. Hasil ini menunjukkan bahwa surfaktan MESA efektif dan menunjukkan peforma yang baik dalam mengubah wettability batuan. Hasil pengukuran sudut kontak batuan disajikan pada Gambar 4. Keberadaan surfaktan dapat mengakibatkan pasangan ion pada formasi dapat bereaksi terhadap perubahan wettability karena gaya tolak elektrostatik antara gugus anionik dan muatan negatif komponen minyak yang teradsorpsi pada permukaan. Surfaktan dapat mengubah kebasahan batuan dengan membentuk monolayer surfaktan pada lapisan batuan yang dibasahi minyak. Adsorpsi surfaktan terjadi melalui interaksi hidrofobik dengan lapisan hidrokarbon yang teradsorpsi pada permukaan batuan, kemudian gugus hidrofilik dari surfaktan bergerak menjauhi permukaan sehingga menjadikan permukaan bersifat hidrofilik (Rosen, 2004; Zhang, 2004). 


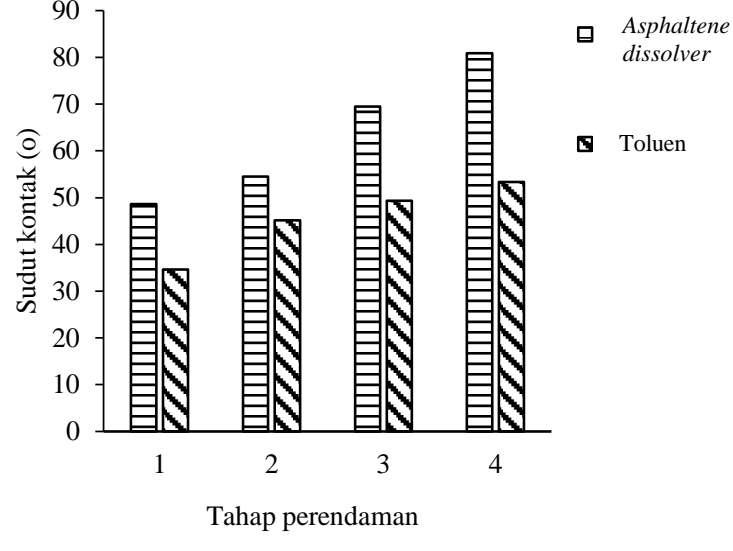

Keterangan:

1 : Perendaman dalam air formasi

2 : Perendaman dalam minyak lapangan A

3 : Perendaman dalam asphaltene dissolver yang dihasilkan

4 : Perendaman dalam air air formasi

Gambar 4. Perbandingan nilai sudut kontak pada permukaan batuan untuk beberapa tahapan perendaman menggunakan asphaltene dissolver dan toluen

Wetting Characteristic pada permukaan logam

Pengujian wetting characteristic bertujuan untuk mengetahui kemampuan asphaltene dissolver yang dihasilkan untuk melepaskan asphaltene dan mengubah sifat kebasahan pada permukaan logam. Pengujian menggunakan logam didasarkan pada kenyataan bahwa fasilitas produksi dan transportasi minyak dan gas bumi umumnya terbuat dari logam dan asphaltene memiliki kecenderungan untuk terdeposisi pada peralatan logam tersebut. Pengujian dilakukan melalui perhitungan pertambahan bobot logam setelah proses pelarutan asphaltene dan pengamatan secara visual perubahan sifat kebasahan yang terjadi dengan ditandai banyaknya jumlah endapan yang masih menempel pada bagian permukaan logam. Pengujian dilakukan terhadap asphaltene dissolver dan toluen.

Berdasarkan Gambar 5 dapat dilihat bahwa sejumlah asphaltene masih terdapat pada potongan logam yang dilarutkan dalam toluen. Kondisi berbeda terjadi pada potongan logam yang dilarutkan dalam asphaltene dissolver dengan menggunakan MESA 1\%. Larutan surfaktan dapat membersihkan atau melepaskan asphaltene dengan baik yang ditandai dengan sangat sedikitnya sisa endapan asphaltene yang berada pada bagian permukaan. Hal ini mengindikasikan bahwa permukaan logam ditinggalkan dalam kondisi water wet. Dari kuantifikasi pertambahan bobot logam setelah pelarutan diperoleh nilai pertambahan bobot sebesar 0,0136 g pada asphaltene dissolver dan pada toluen sebesar 1,4682 g. Hasil ini menunjukkan bahwa pengaplikasian asphaltene dissolver dapat memutuskan ikatan kuat yang terbentuk oleh asphaltene yang terdeposisi pada permukaan logam sehingga asphaltene dapat terlepas dengan baik hingga mencapai $99,32 \%$, sedangkan pada toluen hanya sebesar 26,59\%. Dengan demikian, dapat diketahui bahwa asphaltene dissolver yang dihasilkan menunjukkan peforma yang lebih baik dan memiliki keunggulan dibandingkan toluen dalam melepaskan asphaltene dan mengubah kebasahan pada permukaan logam.

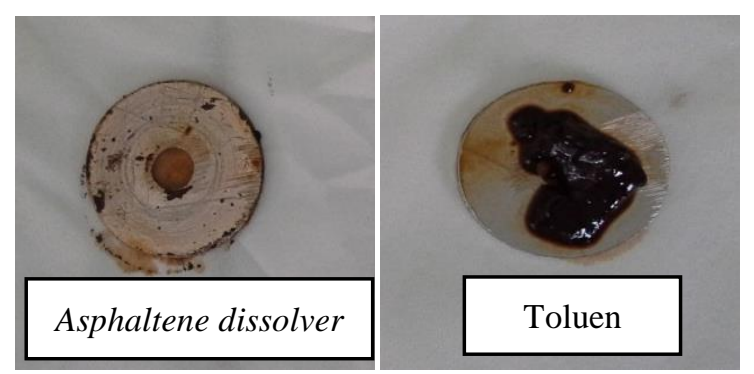

Gambar 5. Kelarutan dan pelepasan asphaltene dari permukaan logam pada penggunaan asphaltene dissolver dan toluen

Surfaktan dapat menyusup ke daerah antarmuka dan mengubah kutub dari permukaan logam, sehingga mengubah sifat kebasahan menjadi lebih suka air (water wet). Menururt Frost et al. (2008) kondisi water wet menunjukkan pengurangan adsorpsi asphaltene secara signifikan pada permukaan. Stabilitas lapisan film air pada permukaan menjadi salah satu faktor menentukan laju adsorpsi dan merupakan fungsi dari kekuatan ion dan $\mathrm{pH}$. Disamping itu, kondisi water wet akan membentuk kompetisi antara lapisan air dan asphaltene yang akan mencegah pembentukan dimer asphaltene, sehingga pembentukan kembali deposisi dapat dicegah.

\section{Filtration Ratio}

Uji filtrasi merupakan indikator untuk menentukan ada atau tidaknya kemungkinan terbentuknya presipitan oleh larutan surfaktan. Kehadiran presipitan ini perlu diketahui dari awal karena kehadirannya dikhawatirkan dapat menyumbat pori-pori batuan reservoir. Pengujian filtrasi dilakukan untuk melihat laju alir fluida (asphaltene dissolver) dalam melewati dinding permeabel dengan ukuran pori tertentu yang merepresentasikan keadaan formasi atau batuan reservoir yang permeabel. Uji filtrasi dilakukan terhadap larutan asphaltene dissolver dengan menggunakan filter membran ukuran 1,2 $\mu \mathrm{m}$, yaitu dengan cara mencatat waktu yang diperlukan untuk melewatkan sejumlah fluida melalui media saring tersebut. Kemungkinan terjadinya presipitasi dilihat dari nilai filtration ratio (FR) yang dihasilkan, dimana semakin besar nilai FR maka kemungkinan terjadinya filtrasi akan semakin besar. Diharapkan laju alir larutan berada pada nilai filtration ratio $(\mathrm{FR})<1,2$. 
Laju alir larutan asphaltene dissolver semakin meningkat seiring dengan semakin besarnya volume larutan yang dilewatkan pada filter membran. Percepatan proses penyaringan semakin meningkat seiring dengan semakin besarnya volume larutan yang dilewatkan. Saat penyaringan pertama kali diduga partikel terlarut mulai tersaring dan tertahan di permukaan pori-pori membran filter. Larutan asphaltene dissolver mengandung partikel terlarut sehingga ketika pertama kali dilewatkan pada filter $1,2 \mu \mathrm{m}$ sebagian besar partikel tersebut tertahan di pori-pori yang menyebabkan perlambatan. Dari kuantifikasi nilai waktu penyaringan dengan volume larutan yang tersaring diperoleh nilai filtration ratio (FR) asphaltene dissolver sebesar 1,14, sehingga asphaltene dissolver dapat dikatakan memiliki kinerja baik dan tidak akan menimbulkan penyumbatan karena memiliki nilai FR pada rentang yang diharapkan yaitu $<1,2$.

\section{KESIMPULAN DAN SARAN}

\section{Kesimpulan}

Asphaltene dissolver terbaik yang dihasilkan adalah campuran surfaktan MESA $1 \%$ dalam toluen yang menghasilkan derajat kelarutan asphaltene sebesar $69,58 \%$ dengan nilai tegangan

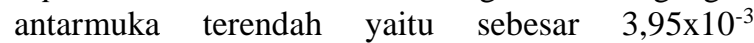
dyne/cm. Asphaltene dissolver yang dihasilkan menunjukkan kinerja yang baik dalam mengubah sudut kontak batuan dari $48,6^{\circ}$ menjadi $80,89^{\circ}$ dan dapat meningkatkan sifat kebasahan pada permukaan logam dengan pelepasan asphaltene sebesar 99,32\% serta memperlihatkan performa dispersi, desorpsi, dan filtrasi yang baik.

\section{Saran}

Pengujian kemampuan asphaltene dissolver pada penelitian ini tanpa melibatkan pengaruh tekanan dan laju alir. Aspek tersebut perlu dikaji untuk mendapatkan hasil yang lebih valid sesuai dengan kondisi aktual di lapangan minyak. Pada penelitian berikutnya dapat dilakukan kajian pengaruh berbagai tingkatan suhu terhadap kinerja asphaltene dissolver.

\section{DAFTAR PUSTAKA}

Frost KA, Daussin RD, dan van Domelen MS. 2008. New, highly effective asphaltene removal system with favorable HSE characterictic. SPE J. 112420:1-16.

Ghaffar AMA, Kabel KI, Farag RK, Maysour NE, Zahran MAH. 2013. Synthesis of poly (dodecyl phenol formaldehyde)- $b$-poly (oxypropylene) block copolymer, and evaluation as asphaltene inhibitor and dispersant. Res Chem Intermed. 41:443445.

Hansen CM. 2007. Hansen Solubility Parameters: A User's Handbook, $2^{\text {nd }}$ ed. CRC Press, Boca Raton, Florida.

Hashmi SM, Zhoung KX, dan Firoozabadi A. 2012. Acid-base chemistry enables reversible colloid to solution transition of asphaltene in non polar system. Soft Matter. 8: 87788785.

Li J, Ali SA, Bustos O, Miller MJ. 2014. Asphaltene removal composition and methods. US Patent No: US 8,695,707 B2.

Lightford S, Pitoni E, Armesi F, Mauri L. 2008. Development and field use of a novel solvent/water emulsion for the removal of asphaltene deposits in fractured carbonate formation. SPE J. 1022:301-311.

Leon O, Rogel E, dan Contreras E. 2001. Amphiphile adsorption on asphaltenes particles: Adsorption isotherms and asphaltene stabilization. Colloid Surf. 189:123-130.

Minssieux L. 2001. Removal of asphalt deposits by cosolvent squeeze: mechanisms and screening. SPE J. 39447:289-301.

Okafor HE, Farshid A, dan Mohammad J. 2013. A computer program to evaluate asphaltene induced formation damage around the near wellbore region. APRN J Eng App Sci.8 (6):419-424.

Oseghale CI dan Ebhodaghe FO. 2011. Asphaltene deposition and remediation in crude oil production: solubility technique. J Eng App Sci. 6 (4): 258-261.

Ostlund JA, Nyden M, Fogler HS, Holmberg K. 2004. Functional groups in fractionated asphaltenes and the adsorption of amphiphilic molecules. Colloid Surf. 234(1): 95-102.

Rosen MJ. 2004. Surfactans and Interfacial Phenomena $3^{\text {rd }}$ ed. New York: Wiley Interscience.

Salgaonkar L dan Danait A. 2012. Enviromentally acceptable emulsion system: an effective approach for removal of asphaltene deposits. SPE J. 160877:1-6.

Surfactant and Bioenergy Research Center (SBRCLPPM IPB). 2012. Prosedur Operasi Baku Pengujian. Bogor: SBRC-LPPM IPB.

Tadros TF. 2005. Applied Surfactants. WILEY-VCH Verlag GmbH \& Co.KGaA: Weinheim.

Zhang J. 2004. Experimental and computational study of nucletae pool boiling heat transfer in aqueos surfactant and polymer solution [Thesis]. University of Science and Technology Beijing. Cina 